\title{
PERAN KELOMPOK INFORMASI MASYARAKAT DALAM PEMBENTUKAN ETIKA DAN PENGEMBANGAN POTENSI MASYARAKAT DESA KARANGSONO
}

\author{
MUFRIDA DEVI ALFIANTI \\ Universitas Islam Balitar \\ Email:Mufridadevi03@gmail.com \\ Anwar Hakim Darajat \\ Dosen Sosiologi Universitas Islam Balitar \\ Email:anwarhakim99@gmail.com
}

\begin{abstract}
ABSTRAK
Penelitian ini bertujuan untuk mengetahui bagaimanakah peran organisasi KIM dalam pembentukan etika dan mengembangkan potensi masyarakat desa Karangsono. Tidak sedikit masyarakat di Desa ini yang belum menemukan ataupun mengembangkan potensi yang mereka miliki. Oleh karena itu KIM dibentuk untuk menjadikan masyarakat yang berpotensial dan beretika. Penelitian ini menggunakan Metode Kualitatif yaitu dengan mengumpulkan data hasil wawancara dengan narasumber. Fokus penelitian ini adalah peran organisasi KIM dalam membentuk etika dan mengembangkan potensi masyarakat Desa Karangsono. Data yang telah diperoleh dari hasil wawancara dikumpulkan dengan baik yang kemudian akan dijadikan sebuah rangkuman. Kesimpulan dalam penelitian ini adalah berbagai upaya telah ditempuh untuk membentuk etika dan pribadi masyarakat menjadi pribadi yang baik serta mengembangkan bakat yang belum tersalurkan. Karena seluruh lapisan masyarakat desa Karangsono belum sepenuhnya mampu untuk mengembangkan bakat mereka. Bahkan tidak semua memiliki etika yang baik. Selain itu, KIM desa Karangsono juga berkomitmen untuk terus berupaya meningkatkan kesejahteraan dan pemberdayaan masyarakat melalui program-program kerja yang telah ditetapkan. KIM dengan bentuk partisipasinya sangat mempengaruhi anggotanya. Organisasi ini membantu tentang bagaimana cara mengambil sebuah keputusan dan bertindak secara tepat dalam sebuah kehidupan. Oleh karena itu dengan adanya organisasi ini, diharapkan etika yang dimiliki masyarakat memiliki nilai positive dan potensi masyarakat akan berkembang sesuai dengan bakat yang mereka miliki.
\end{abstract}

Kata kunci : organisasi, etika, dan potensi.

\begin{abstract}
This study aims to determine how the role of KIM organization in the formation of ethics and potential development of the village community Karangsono. The number of people who are still hesitant to plunge into an organization, so that people can not live alone, in fulfilling the needs of life will form a group which then called the organization. This research uses Qualitative Method that is by collecting data result of interview with informant. The focus of this research is the role of KIM organization in the formation of ethics and the development of community potency of Karangsono Village. The data that have been generated from the results of
\end{abstract}


interviews with both the later will be a summary. In this study are various efforts taken to form ethics and personal society into a good person and develop talents that have not been channeled. Because the whole community of Karangsono village can not yet be built to develop their talents. Not all have good ethics yet. In addition, KIM Karangsono village is also committed to continuously improve the welfare and empowerment of the community through established work programs. KIM with its participation form greatly affects its members. This organization helps on how to make the right decisions and actions in a life. Therefore, with this organization, it is expected that the ethics of the community has a positive value and the potential of the community will develop in accordance with the talent they have.

\section{Keywords: organization, ethics, and potential.}

\section{PENDAHULUAN}

Bagaimana organisasi KIM Desa Karangsono membentuk etika masyarakat terutama kaum muda di era informasi seperti ini? Tidak semua lapisan masyarakat tertarik mengikuti organisasi. Banyak factor yang menyebabkan mereka enggan masuk kedalam suatu perkumpulan. Anak muda jaman sekarang lebih aktif perkumpulan di media social, baik grup WhatssApp, BBM, Line, dan lain-lain. Secara tidak langsung akun-akun tersebut membuat mereka akan malas untuk berinteraksi langsung dengan orang lain. Banyak manfaat dengan adanya social media tersebut, namun mereka malah terjerumus didalamnya. Dengan begitu akan terasa yang jauh menjadi dekat, dan yang dekat menjadi jauh. Padahal hal demikian tidaklah baik, karena pada dasarnya mengikuti organisasi merupakan sarana pengembangan diri.

Berbagai persoalan dan kerusakan yang ada saat ini sesungguhnya dikarenakan oleh kondisi moral dan etika masyarakat yang sudah mengalami penurunan. Kemerosotan moral dan etika bangsa ini semakin terlihat jelas saat persoalan demi persoalan bangsa semakin hari bukan semakin hilang, tetapi justru semakin meningkat tajam. Mulai dari kasus kekerasan baik secara pribadi maupun kelompok, ketidakadilan sosial dan hukum, hingga budaya korup penguasa yang makin merajalela.

Untuk mengembalikan moral dan etika ditengah-tengah kondisi bangsa yang sudah rapuh memang bukan suatu perkara yang mudah. Dibutuhkan perjuangan keras untuk mewujudkannya. Generasi penerus bangsa harus dilatih menjadi suatu pribadi yang baik dan berpotensi. Oleh karena itu salah satu upaya pemerintah untuk mengatasi permasalahan tersebut yaitu dengan membentuk KIM supaya masyarakat dapat memberdayakan informasi supaya memberikan nilai tambah bagi masyarakat 
Desa Karangsono serta supaya masyarakat lebih memiliki pengalaman dan pengetahuan. Masyarakat akan dilatih menjadi suatu pribadi yang produktif, kretif, dan inovatif. Dengan adanya suatu permasalahan yang telah dihadapi maupun masalah yang akan datang, tentunya sangatlah penting bagi masyarakat khususnya kaum muda Desa Karangsono untuk selalu membiasakan diri dalam hal meningkatkan dan memperbaiki produktifitas Desa. Sehingga Desa tidak tertinggal dengan masyarakat desa lainnya.

Maju tidaknya suatu Desa bergantung pada masyarakat desa tersebut. Peranperan masyarakat dalam membantu lancarnya pemerintahan sangat diperlukan. Oleh karena itu KIM merupakan sebuah pergerakan yang sangat mampu membantu proses pemerintahan, karena organisasi KIM dapat membantu dan mengajak masyarakat untuk lebih aktif dalam kehidupan lingkungannya.

Dalam era informasi global sekarang ini, keberadaan Kelompok Informasi Masyarakat (KIM) masih diperlukan. Masyarakat berhak dalam mengakses informasi, dan pemerintah berkewajiban membuka akses tersebut. KIM dapat membantu Pemerintah dalam menyebarkanluaskan informasi, yakni informasi yang mengubah cara pandang masyarakat, seperti informasi kebijakan pemerintah, berita mengenai keberhasilan anak bangsa yang berprestasi dan informasi yang layak untuk disebarluaskan dan di implementasikan dalam kehidupan sehari-hari.

Bukan hanya sebagai penyalur informasi, tetapi KIM juga merupakan wadah dimana seseorang dapat saling berbagi pengalaman. Dengan mendengarkan pengalaman setiap orang yang berbeda, dapat digunakan sebagai pembelajaran. Dengan demikian seseorang akan mengerti bahwa segala sesuatu memiliki alasan tersendiri mengapa hal itu terjadi.

Bukan hanya sebagai penyalur informasi, tetapi KIM juga sebuah perkumpulan yang menjadikan anggotanya menjadi lebih kuat dan bijaksana dalam memandang sebuah permasalahan dan siap untuk mengahadapi tekanan yang jauh lebih berat lagi. Dalam rangka memperbaiki kondisi kehidupan menjadi lebih baik tentunya dengan cara menggerakkan partisipasi masyarakat daerah itu sendiri. Bukan hanya itu, Kelompok Informasi Masyarakat (KIM) juga mengajarkan tentang bagaimana menjadi bijak dalam berbicara dan juga mengajarkan untuk tidak lagi salah melangkah dan gegabah dalam mengambil keputusan. Karena apabila salah 
mengambil keputusan, dampaknya tidak hanya pada satu orang saja, melainkan seluruh anggota yang terdapat didalamnya.

Pada tingkat pribadi, jika seorang anggota merasa bahwa sebuah organisasi memenuhi kebutuhan dan karakteristik individualnya, maka ia akan cenderung berperilaku positif. Tetapi sebaliknya, jika anggota tidak merasa diperlakukan dengan adil, maka mereka akan cenderung untuk tidak tertarik melakukan hal yang terbaik (Cowling dan James, 1996). Untuk itu, ketika seseorang mempunyai ketertarikan yang tinggi terhadap suatu pekerjaan, seseorang akan menunjukkan perilaku terbaiknya dalam bekerja (Duran-Arenas et.al,1998).

\section{Pengertian Organisasi}

Menurut Dr.Sondang P. Siagian organisasi merupakan bentuk persekutuan antara dua orang atau lebih yang bekerjasama secara formal dan terikat untuk mencapai sebuah tujuan yang ditentukan.

Maksudnya ialah organisasi merupakan suatu kerja sama sekelompok orang dengan mengunakan sumber daya tertentu untuk berusaha mencapai tujuan yang sama juga untuk menyalurkan suara atau pendapat dan wadah untuk melakukan kegiatan bersama. Dengan kata lain bahwa organisasi terdiri dari orang-orang yang bekerja dalam suatu system pencarian tujuan yang sama.

\section{Pengertian KIM}

Menurut Direktorat Kelembagaan Komunikasi Sosial (2008:1) yang dimaksud dengan KIM (Kelompok Informasi Masyarakat) ialah lembaga layanan public yang dibentuk dan di kelola dari, oleh dan untuk masyarakat yang berorientasi pada layanan informasi dan pemberdayaan masyarakat sesuai dengan kebutuhannya.

Dari uraian penjelasan diatas dapat disimpulkan bahwa KIM merupakan media / forum yang memiliki kegiatan mengikuti informasi dari berbagai sumber yang kemudian disalurkan kepada masyarakat untuk di implementasikan sehingga mewujudkan masyarakat yang berpotensial.

\section{Faktor Pendukung KIM}

Menurut Liton (Krisari, 2007) menjelaskan bahwa factor pendukung sebuah kelompok masyarakat ialah fasilitator informasi yang merupakan pendidik oleh lembaga diklat pemerintah maupun Non pemerintah.

KIM bukanlah sebuah organisasi yang mampu berdiri sendiri. KIM merupakan organisasi yang memiliki factor pendukung demi keberhasilan dan 
kelancaran seluruh aktifitasnya, salah satu factor tersebut ialah seseorang/sekelompok pendidik baik itu permerintah maupun Non pemerintah.

\section{Faktor Penghambat KIM}

Menurut Marheni Fajar (2009:62), hambatan terjadi disebabkan karena kurangnya perhatian saat mendengarkan / menerima informasi, sehingga dapat menimbulkan tanggapan yang kurang benar dan tidak mencari informasi lebih lanjut.

Selain memilik factor pendukung, KIM juga memiliki saktor yang menghambat jalannya sebuah organisasi, salah satunya ialah kesalahpahaman mengenai informasi yang disebabkan oleh kurang memperhatikannya masyarakat atau kurang jelasnya dalam penyampaian informasi.

\section{METODE PENELITIAN}

Penelitian ini menggunakan metode kualitatif, karena penelitian ini hanya terfokus pada upaya-upaya yang dilakukan pemerintah dalam pembentukan etika dan pengembangan potensi melalui wawancara dengan salah satu anggota organisasi yang kami teliti.

Obyek dalam penelitian ini adalah upaya-upaya yang dilakukan pemerintah dalam pembentukan etika dan pengembangan potensi masyarakat desa Karangsono, sedangkan subyek penelitian ini mengambil salah satu organisasi yang terdapat di desa Karangsono yaitu organisasi KIM (Kelompok Informasi Masyarakat)

Data yang kami peroleh untuk menulis laporan penelitian ini adalah data yang kami dapatkan melalui wawancara dengan salah satu anggota KIM di Desa Karangsono, namun sebagian juga dari pandangan masyarakat setempat (yang bukan anggota), karena kami ingin mengetahui bagaimana pandangan mereka mengenai organisasi ini.

Teknik pengumpulan data yang digunakan dalam penelitian ini adalah survey dan dokumentasi. Dengan teknik ini kami mengajukan beberapa pertanyaan kepada narasumber mengenai beberapa masalah dalam berorganisasi.

\section{PEMBAHASAN}

Dalam Pembahasan ini, penulis akan menganalisis dan menggambarkan tentang bagaimana peran organisasi KIM dalam mewujudkan masyarakat Desa Karangsono supaya beretika dan berpotensial. 
Seorang pemuda adalah tokoh masa depan Indonesia. Masa muda adalah masa dimana banyak rasa keingintahuan. Dengan adanya rasa tersebut mereka akan menggali banyak informasi dari berbagai macam sudut. Apalagi di zaman teknologi seperti ini akan terasa lebih mudah mendapatkan sumber informasi. Untuk menghadapi pertumbuhan ekonomi dan sosial kaum muda harus mempersiapkan dirinya agar menjadi orang yang matang dalam artian siap dan tanggap. Dan organisasi menjadi suatu wadah untuk proses pematangan kaum muda tersebut. Oleh karena itu, dengan dibentuknya organisasi KIM ini sangat membantu kaum muda untuk lebih berkarya, karena KIM ini memanfaatkan teknologi untuk memperoleh sebuah informasi.

Maksud dari pembentukan KIM adalah untuk mewujudkan masyarakat yang aktif terhadap informasi, karena informasi dapat membuat kemajuan sebuah lingkungan supaya tidak tertinggal arus informasi secara mandiri dan tidak bergantung kepada pemerintah. Kelompok Informasi Masyarakat (KIM) merupakan sebuah organisasi dimana sebagai wadah bagi masyarakat untuk saring bertukar informasi, sharing pengalaman, pelatihanm minat dan bakat. Oleh karena itu, peluang untuk mengembangkan bakat serta bisnis kaum muda dalam memasuki dunia usaha dan era digital sangatlah besar karena banyak pelatihan didalamnya.

Banyak manfaat yang dapat diambil dengan mengikuti organisasi KIM. Bukan hanya teori belaka, namun anggota akan memiliki banyak pengalaman di lapangan baik secara internal maupun eksternal. Selain itu Kelompok Informasi Masyarakat juga akan mengasah jiwa kepemimpinan kita. Tidak harus mengikuti sebuah organisasi yang besar, karena segala sesuatu tergantung pada niat. Walaupun seseorang memilih untuk mengikuti sebuat organisasi yang besar, namun mereka tidak peduli (acuh), maka hasilnya akan berbeda dengan mereka yang hanya mengikuti sebuah organisasi kecil namun sangat aktif di dalamnya. Segala macam permasalahan yang di hadapi sebuah organisasi, membuat seseorang semakin matang dan dewasa. Dengan begini, maka generasi penerus bangsa akan menjadi pribadi yang siap untuk menghadapi persaingan mendatang.

Adapun rincian kegiatan yang dilakukan oleh anggota KIM adalah sebagai berikut:

1. akses informasi

2. Diskusi tentang informasi

JURNAL TRANSLITERA EDISI 5/2017 
3. Implementasi Informasi yang diperoleh

4. Networking (jaringan kelembagaan)

5. Diseminasi (seleksi, Pengolahan dan Penyebaran informasi)

6. penyerapan dan penyaluran informasi masyarakat

Disamping itu dengan adanya KIM akan memudahkan masyarakat untuk menyalurkan suara daripada melakukan suatu hal secara individu. Dengan adanya struktur organisasi dan pembagian tugas yang jelas, maka apabila menemukan suatu permasalahan dalam berorganisasi dapat diselesaikan bersama-sama.

Oleh sebab itu, KIM diharapkan menjadi sarana komunikasi antara pemerintah daerah dengan masyarakat langsung. Dengan mengikuti organisasi ini, utamanya anggota KIM sendiri akan terbiasa akan adanya dipimpin atau memimpin. Mungkin jika masyarakat masih awal mengikutnya, maka masyarakat akan berada pada tahap dipimpin. Namun tak selamanya akan terus pada posisi tersebut. Jika jiwa kepemimpinan anggota meningkat, lambat laun ia akan memimpin organisasi tersebut.

\section{Pembentukan Etika}

Etika menjadi unsur penting dalam kehidupan bersosial. Etika Masyarakat merupakan segala hal yang mengatur masyarakat dalam kehidupan sehari-hari watak, perasaan, sikap, adat istiadat, dan pola berpikir. Tanpa etika, manusia akan hidup semaunya tanpa memperhatikan yang lain. Oleh karena itu etika sangat dibutuhkan atau bahkan penting dalam sebuah kehidupan. Zaman sekarang tidak sedikit kaum muda yang kehilangan etika dan moral. Untuk menjadi sebuah warga kita harus menaati peraturan yang ada. Dalam hal ini, etika sangat dibutuhkan dalam menjalankan aturan tersebut, karena dengan menggunakan etika yang dimiliki, akan tercipta kehidupan yang damai dalam bermasyarakat.

Etika menjadi tolak ukur dalam menghadapi berbagai perbedaan pola pikir yang ada di masyarakat. Sehingga masyarakat dapat berargumentasi secara kritis dan rasional serta dapat mengambil sikap wajar dalam menghadapi situasi apapun. Etika terkadang dibentuk dari kebiasaan tingkah laku yang telah terjadi secara turun temurun yang sudah dilakukan oleh nenek moyang. Etika terkadang juga berasal dari nilai keagamaan yang dianut oleh masyarakat. Sehingga etika pada umumnya adalah segala jenis hukum yang mengatur moral, adat dan kesopanan dalam bermasyarakat. 
Prof.Dr.Sondang P.Siagian dalam bukunya yang berjudul Analisis serta Perumusan Kebijaksanaan dan Strategi Organisasi mengatakan "karena lingkungan masyarakat dekat merupakan "arena" pergaulan yang dihadapi setiap hari, jelas pengaruhnya terhadap pembentukan etika akan sangat besar. Artinya, apabila seseorang selalu melihat bahkan mungkin juga terlibat dalam gaya hidup yang tentram, damai, penuh toleransi dan menyenangkan, perilakunya pun bertumbuh menjadi perilaku yang positif. Sebaliknya, dalam suasana saling curiga mencurigai, tidak aman, dan kotor, sukar membayangkan berkembangannya perilaku positif meskipun para orangtua dan para pendidik telah berusaha keras kearah itu”.

Sebagai organisasi yangberhubungan langsung dengan pemerintah, KIM dan Pemerintah bekerjasama dalam hal membangun jati diri bangsa dalam hal sikap etika dan perilaku yang berbudaya atas asas Pancasila dan menumbuhkan kesadaran akan pentingnya generasi muda untuk selalu berkarya dan terampil sehingga menciptakan masyarakat yang berpotensial. Dalam menjalankan tugasnya, pemerintah tentu membutuhkan partisipasi masyarakat dalam membangun sarana dan prasarana. Supaya partisipasi masyarakat tumbuh, diperlukan kebijakan dan langkah yang tepat. Organisasi sosial seperti KIM merupakan organisasi yang sudah ada di masyarakat sangat berarti untuk pemetintah dalam menjalankan tugasnya.

Dengan mengikutsertakan diri dalam organisasi KIM, etika-etika yang terpuji akan tumbuh dengan sendirinya karena adanya pelatihan dan keterbiasaan menghadapi sebuah permasalahan. Tidak hanya itu, factor lingkungan juga mempengaruhi etika seseorang, lingkungan yang baik akan menumbuhkan jiwa yang baik dan lingkungan yang kurang baik juga akan menumbuhkan jiwa yang kurang baik pula. Dalam suatu permasalahan berorganisasi, akan menumbuhkan jiwa yang bertanggung jawab, disiplin, bahkan jiwa kepemimpinan. Oleh karena itu organisasi KIM sangatlah berperan bagi para pemuda penerus bangsa terutama Masyarakat Desa Karangsono.

Terjun dalam organisasi KIM tentu akan memiliki kesempatan untuk bertemu dengan banyak orang yang menginspirasi. Anggota tentu akan bertemu dengan orang yang berbeda latar belakang, dan yang paling utama adalah perbedaan pemikiran antar individu. Oleh karena itu, setiap anggota belajar untuk siap dalam mengahadapi segala komentar yang diterima. Dari sinilah sikap saling menghargai akan muncul. Tentang bagaimana seseorang harus menyikapi sebuah perbedaan, 
sehingga akan terbiasa melihat segala hal dengan sudut yang berbeda yang akan membuat fikiran lebih terbuka dan tidak egois.

Sebuah organisasi selalu menghadapi suatu masalah yang bertentangan dengan aturan yang ada, khususnya organisasi KIM. Anggota akan diajarkan mengenai apa yang harus mereka lakukan jika harus mengikuti perintah yang secara pribadi mereka tidak setuju? Masalah inilah yang akan menumbuhkan sikap kejujuran dengan menilai kinerja baik bagi yang mereka sukai, dan menilai kinerja kurang baik yang tidak mereka sukai. Dari sinilah kejujuran akan di uji, apakah kita mampu bersikap bijaksana atau sebaliknya.

Dengan mengikuti organisasi KIM ini, tentunya berdampak pada pergaulan dan banyaknya relasi yang mereka temukan. Dengan bergaul diluar, mereka belajar bagaimana menjadi orang yang easy going sehingga bisa diterima, belajar tentang tata cara pertemanan yang baik, berpendapat dan masih banyak lainnya sehingga menjadikan generasi penerus bangsa yang beradab dan memiliki etika dan moralitas yang baik. Hal ini juga yang mendorong potensi baik dalam diri anggota yang membuat mereka mau berteman dengan siapa saja dna mampu membuka jaringan relasi yang lebih luas.

\section{Pengembangan Potensi}

Seberapa besar potensi seseorang, faktanya masih banyak yang terpendam dan dibiarkan begitu saja. Tidak semua orang mampu menemukan potensi dirinya, bahkan walau hanya mengenalinya di dalam diri mereka. Hal ini tidak boleh terjadi begitu saja. Sebagai makhluk yang dikaruniai akal fikiran, harus dapat menggali, mengembangkan, dan memanfaatkan potensi yang dimiliki. Bukan hanya untuk kepentingan pribadi semata, melainkan juga untuk kepentingan bersama dalam sebuah organisasi. Seorang pemuda tidak boleh cepat merasa puas atas apa yang telah ia capai, karena jika ia mudah puas maka mereka akan berhenti untuk terus berkarya. Mereka harus terus berjuang supaya potensi mereka lebih berguna. Begitu banyak yang dapat kita lakukan di dunia ini. Namun juga banyak keterbatasan yang menghambat untuk melakukannya. Banyak hal baru yang harus dicoba. Dengan begitu lambat laun potensi yang selama ini tersembunyi akan terlihat oleh kita.

KIM sangat berpengaruh untuk tercapainya sebuah tujuan masyarakat di suatu desa. Karena tanpa adanya KIM, informasi yang seharusnya diketahui oleh 
masyarakat tidak akan tersalurkan begitu saja tanpa adanya perantara. Dengan berbagai informasi yang masuk, maka masyarakat akan memperoleh pengetahuan yang luas. Oleh karena itu, organisasi KIM diharuskan untuk bersikap transparan, dalam artian jika terdapat suatu informasi mereka tidak boleh menutupinya atau menjadikan informasi tersebut untuk anggota mereka sendiri.

Berbagai upaya telah dilakukan oleh anggota KIM agar informasi yang diperoleh memberi nilai tambah bagi masyarakat Desa Karangsono untuk terus maju dan berkembang. Agar menjadi pribadi yang lebih berpotensi, masyarakat dituntut untuk terus berfikir dan bergerak, bukan hanya diam saja tanpa adanya impian untuk sebuah tujuan. Bukan hanya mimpi, namun harus disertai dengan kerja keras yang memadai.

Sebagai tahap penelitian, peneliti memilih beberapa informan, untuk dijadikan sebagai narasumber guna memberikan informasi seputar permasalahan KIM di Desa Karangsono yaitu anggota masyrakat yang terjun langsung ke dalam organisasi KIM.

'Sebenarnya awalnya saya mengikuti oragnisasi ini hanya asalasalan. Tetapi setelah saya mengikuti berbagai kegiatan di organisasi ini lebih banyak pengalaman yang saya dapatkan. Mulai dari kepemimpinan, toleransi, dan kebersamaan.' Ujar Agus (salah satu anggota KIM desa Karangsono)

Oleh karena itulah organisasi memiliki peranan yang penting bagi masyarakat dalam kehidupan bersama. Dalam sebuah organisasi diajarkan bahwa sikap toleransi merupakan sikap yang harus ada pada diri manusia supaya tidak terjadi perselisihan yang dapat memgakibatkan ketidakentraman bermasyarakat.

Organisasi KIM banyak dimasuki oleh berbagai kalangan dalam melakukan kewajiban-kewajiban sosialnya, dalam semua segi kehidupan seperti di bidang politik, ekonomi, maupun sosial budaya. Untuk meningkatkan SDM dan kelembagaan, organisasi KIM belum lama ini telah menyelenggarakan kegiatan Pengembangan Jiwa Kewirausahaan Generasi Muda. Pelatihan disini adalah pengembangan keterampilan anggota dan moral anggota melalui pendidikan dan pelatihan.

Jika masyarakat mampu menggali potensi mereka dengan baik dengan cara ikut berpartisipasi dalam Kelompok Informasi Masyarakat (KIM) yang merupakan 
salah satu organisasi masyarakat yang berhubungan langsung dengan pemerintah, maka masyarakat sebuah desa akan memiliki potensi yang dapat dijadikan sebagai kekuatan serta peluang untuk mengembangkan pembangunan desa menjadi lebih baik. Berikut ini uraian potensi yang dimiliki oleh desa Karangsono dalam berbagai aspek:

1. Aspek Agama

Mayoritas masyarakat Desa Karangsono beragama Islam. Potensi agama Desa Karangsono ialah banyaknya kegiatan rohani seperti pengajian yang dilaksanakan setiap minggunya, perayaan hari besar agama. Dengan demikian masyarakat memiliki nilai religious yang sangat tinggi. Di Desa Karangsono juga terdapat pondok pesantren, guna untuk menunjang sarana pendidikan tentang keagamaan supaya lebih optimal.

2. Aspek Sumber Daya Alam (SDA)

Melihat kondisi geografis dan kondisi lingkungan desa, Desa Karangsono memiliki banyak potensi yang dapat dikembangkan. Dari aspek sumber daya alam, potensi yang ada di Desa Karangsono ialah banyaknya lahan subur yang dapat digunakan untuk bertani sehingga dapat memenuhi kehidupan. Dengan demikian masyarakat desa akan lebih potensial dalam hal pangan sehingga tidak perlu membeli pada daerah lain. Peduduk desa Karangsono mengelola dan memanfaatkan tanah sebagai lahan pertanian untuk mencukupi kebutuhannya sendiri. Bahkan hasil dari tani tersebut dapat diperjualbelikan untuk memenuhi kebutuhan ekonomi daerah lain seperti daerah kota. Orang kota membutuhkan hasil pertanian dari desa, dan sebaliknya orang desa membutuhkan hasil produk industri dari kota. Selain itu sawah, perkebunan dan pekarangan yang luas merupakan potensi utama desa yang juga mendukung pengembangan SDA supaya lebih produktif dan mendapat hasil yang maksimal.

3. Aspek Pendidikan

Di Desa Karangsono memiliki lembaga pendidikan mulai dari tingkat PAUD hingga tingkat SMP. Selain itu juga terdapat lembaga pendidikan agama yakni Madrasah Diniyah.

Masyarakat Desa Karangsono merupakan potensi bagi desa. Masyarakat mengolah potensi sumber daya yang dimiliki supaya menjadi desa yang lebih 
produktif. Desa Karangsonojuga memiliki jumlah penduduk yang banyak dengan berbagai keterampilan sehingga memberikan sumbangan bagi pendapatan desa tersebut. Karena pada dasarnya selain factor letak geografisnya, kemakmuran dan kemajuan desa ditentukan oleh usaha penduduk. Desa yang memiliki banyak SDA tetapi penduduknya tidak cukup mempunyai semangat, keterampilan, dan pengetahuan untuk membangun desa dapat mengakibatkan desa tersebut kurang maju. Sebaliknya, meskipun desa memiliki Sumber Daya Alam terbatas tetapi memiliki penduduk yang terampil, berpengetahuan, dan bersemangat dalam membangun desa sehingga mampu mengendalikan hambatan alam dan geografis wilayah maka desa tersebut akan cepat maju.

Sebagai pemuda penerus bangsa, tentu harus dipersiapkan dan dilatih dengan baik. Mengikuti organisasi ini bukanlah suatu hal yang sia-sia dan tidak bermanfaat. Bahkan sebaliknya, organisasi KIM ini sangat bermanfaat bagi pembentukan karakter masyarakat desa di masa yang akan datang. Jika karakter masyarakatnya rusak, maka rusak pula kehidupan berbangsa dan bernegaranya. Begitu juga sebaliknya.

Anak muda adalah mereka yang memiliki dunia yang menyenangkan, dunia yang penuh dengan kegembiraan dan bahkan banyak orang yang sudah tua ingin kembali ke masa muda mereka. Karena disaat kita masih muda, kita bisa melakukan apa saja yang kita inginkan. Mengembangkan karir, mengembangkan prestasi, mengembangkan hobi dan masih banyak lainnya. Atas alasan inilah para pemuda Desa Karangsono tidak ingin membuang masa mudanya dengan sia-sia. Dengan semangat kebersamaan, mereka membuat sebuah organisasi kemasyarakatan yang sangat bermanfaat bagi mereka sendiri dan seluruh anggota masyarakat yang merasakan.

Bukan hanya sebagai wadah masyarakat dalam mengaspirasikan kehendak politiknya, organisasi KIM memberi dimensi yang lebih luas melalui mengikutsertakan anggota dalam setiap kegiatan pelatihan, yang dapat meningkatkan bakat dan potensi masyarakat. Wadah ini memepersilakan setiap anggotanya untuk mengembangkan potensi, bakat dan kegemaran yang dimiliki. Berikut ini beberapa contoh kegiatan KIM Karangsono dalam upaya pengembangan potensi dan pelatihan masyarakat: 
1. Tanam Bersama. Dinas Pertanian Kab.Blitar Poktan Kec.Kanigoro bertempat di desa Karangsono. Kegiatan ini bertujuan untuk mensosialisasikan kepada petani bagaimana cara menanam padi yang baik dan benar agar hasil panen dari petani lebih berkualitas serta dapat mewujudkan program pemerintah dengan Swasembada Pangan.

2. Pelatihan Batik Tulis. Pelatihan ini bertujuan untuk meningkatkan kualitas, produktifitas, serta mengembangkan potensi masyarakat khususnya para pengrajin batik, umumnya untuk seluruh masrarakat terutama kaum muda di desa Karangsono.

3. Pelatihan kerja para pemuda. KIM bersama pemerintah Desa Sukolilo bekerja sama dengan Disnakertan Provinsi Jawa Timur dalam bidang. Dengan diadakannya kegiatan ini, organisasi KIM mempunyai peluang yang besar untuk tumbuh dan berkembang di masa yang akan dating melalui para anggotanya yang akan memiliki kesempatan yang luas pula untuk mengembangkan potensinya menjadi kemampuan nyata

Keberadaan Kelompok Informasi Masyarakat (KIM) di dalam lingkungan desa Karangsono harus terus dihidupkan dengan adanya kesadaran para pemuda masyarakat Desa Karangsono untuk berperan aktif didalamnya. Bukan hanya sebagai tempat pengembangan potensi diri namun KIM juga menciptakan sebuah ruang dimana terjalinnya suatu komunikasi antar individu.

\section{Kesimpulan}

Berdasarkan hasil penelitian dan pengamatan dari penulis dengan mewawancarai beberapa orang anggota KIM tentang peran KIM dalam pembentukan etika dan potensi masyarakat Desa Karangsono dapat disimpulkan bahwa KIM di Desa Karangsono sangat berperan penting dalam pengembangan etika dan potensi masyarakat utamanya di Desa Karangsono. Dengan memanfaatkan potensi lokal dan partisipasi masyarakat dalam membangun sebuah Desa yang mandiri, KIM mampu mengikuti program pemerintah untuk memajukan desa. Selain itu, KIM juga dijalankan dengan maksud supaya masyarakat Desa Karangsono tidak tertinggal dalam hal informasi sehingga dalam struktur potensial masyarakat tidak terhambat yang dikarenakan ketertinggalan tersebut. Sebenarnya tugas KIM sendiri adalah forum penyebaran Informasi kepada masyarakat, namun keberadaan KIM tidak jauh 
berbeda dengan Karang Taruna. Mereka akan bekerja sama supaya masyarakat lebih terdidik dan terlatih dalam segala aspek, baik aspek sosial dalam suatu komunikasi dan etika maupun aspek potensial.

\section{Daftar Pustaka}

Pace, R Wayne dan Don F. Faules. 2015. Komunikasi Organisasi. Bandung : PT Remaja Rosdakarya.

Sigit, Soehardi. 2003. Esensi Perilaku Organisasi. Yogyakarta : Lukman Offset.

Sawaf, Ayman. 2002. Executive EQ. Jakarta : Gramedia Pustaka Utama.

Smith, Perry M. 1994. Mengemban tanggung jawab dan mengambil pilihan yang tepat. Jakarta : Mitra Utama.

Pareek, Udai. 1985. Mendayagunakan peran-peran keorganisasian. Jakarta : Pustaka Binaman Presindo.

Soetopo, Hendyat. 2012. Perilaku Organisasi. Bandung : Remaja Rosdakarya.

Mesiono. 2010. Manajemen dan organisasi. Bandung : Cita Pustaka Media Perintis.

Lexy J, Moelong. 2010. Metode Penelitian Kualitatif. Bandung : PT. Remaja Rosdakarya Offset.

Patilima, Hamid. 2006. Metode Penelitian Kualitatif. Bandung : ALFABETA.

Moleong, L J. 2006.Metode Penelitian Kualitatif. Bandung : PT. Remaja Rosdakarya. 